Academic goals, learning strategies and social anxiety / Metas académicas, estrategias de aprendizaje y ansiedad social

\title{
Academic goals and learning strategies in Secondary Education Spanish students with social anxiety / Metas académicas y estrategias de aprendizaje en estudiantes españoles de Educación Secundaria Obligatoria con ansiedad social \\ Beatriz Delgado a, David Aparisi ${ }^{\mathrm{a}}$, José M. García-Fernández ${ }^{\mathrm{a}}$, María S. Torregrosa ${ }^{\mathrm{b}}$, Estefanía Estévez ${ }^{\mathrm{c}}$, Juan Carlos Marzo ${ }^{\mathrm{c}}$ and Cándido J. Inglés ${ }^{\mathrm{c}}$ \\ ${ }^{a}$ Universidad de Alicante ${ }^{b}$ Universidad Católica San Antonio de Murcia ${ }^{c}$ Universidad Miguel Hernández de Elche
}

(Received 2 December 2016; accepted 14 June 2017)

\begin{abstract}
The purpose of this study was to analyse the relationship between high social anxiety, academic goals and learning strategies in a sample of 2022 (51.1\% male) Spanish adolescents aged 12 to 16. The Social Phobia and Anxiety Inventory (SPAI), Achievement Goal Tendencies Questionnaire (AGTQ) and Learning and Studies Skills Strategies Inventory - High School Version (LASSI-HS) were used to assess the variables. The results showed no statistically significant differences in goal orientations between students with and without high social anxiety. However, students with high social anxiety used learning strategies significantly less. In addition, the logistic regression results indicated that high social anxiety acts as a significant predictor for setting social recognition goals and learning and study strategies.
\end{abstract}

Keywords: adolescence; social anxiety; learning strategies; secondary education; academic goals

Resumen: El objetivo de este estudio fue analizar la relación entre la alta ansiedad social, las metas académicas y las estrategias de aprendizaje en una muestra de 2022 (51.1\% varones) adolescentes españoles de 12 a 16 años. Las variables fueron evaluadas mediante los cuestionarios Social Phobia and Anxiety Inventory (SPAI), Achievement Goal Tendencies Questionnaire (AGTQ) y Learning And Studies Skills Inventory - High school (LASSI-HS). Los resultados no mostraron ninguna diferencia estadísticamente significativa en las orientaciones de meta entre estudiantes con y sin alta ansiedad social. No obstante, los estudiantes con alta ansiedad social utilizaron significativamente menos estrategias de aprendizaje. Asimismo, los resultados obtenidos de la regresión logística señalaron que la alta ansiedad social actúa como predictor significativo de las metas de reconocimiento social y de las estrategias de aprendizaje y estudio.

Palabras clave: adolescencia, ansiedad social, metas académicas, estrategias de aprendizaje, educación secundaria

Translation from Spanish/ Traducción del español: Liza D’Arcy

Author's Address / Correspondencia con los autores: Beatriz Delgado. Departamento de Psicología Evolutiva y Didáctica. Universidad de Alicante. Apartado de correos 99, 03080, Alicante, España. Teléfono: +34 965903495. E-mail: beatriz.delgado@ua.es. 
Social anxiety is characterized by an intense and persistent fear of one or more social situations where the person is exposed to unfamiliar people or to possible analysis by others (American Psychiatric Association, 2013). The problem is of moderate prevalence, usually begins during early adolescence and generates considerable interference with children's academic adjustment and social development. Thus, high absenteeism, poor participation in class, and the tendency to avoid asking the teacher questions (Bernstein, Bernat, Davis \& Layne, 2008) results in the anxious student not being able to corroborate their learning and thus obtain lower academic qualifications (Delgado, Inglés \& García-Fernández, 2014). Likewise, when they avoid creating relationships with other students their peers react by not accepting them (Inglés, Delgado, García-Fernández, Ruiz-Esteban \& Díaz-Herrero, 2010), which results in a negative perception of themselves (Delgado, Inglés and García-Fernández, 2013) their school. However, little is known about how students with social anxiety self-regulate their learning. The purpose of this study is to analyse the academic goals of adolescent with anxiety who have difficulties relating socially as well as their use of learning strategies.

\section{Adolescents’ Academic Goals and Relationship to High Social Anxiety}

Goals can be defined as an integrated pattern of thoughts and reasons for behaviours that individuals develop within a context of achievement (Linnenbrink \& Pintrich, 2000). Goal orientation and setting is important because it reflects the individual's self-concept (Inglés et al., 2015), effectiveness in information processing and persistence in tasks they carry out, which in turn have an impact on school performance.

The relationship between social anxiety and academic goals in secondary school students has been poorly analysed. In this sense, Cantwell and Andrews (2002) analysed 
the relationship between interest, motivational goals, metacognitive awareness, need for association, feelings in work groups and social anxiety in a sample of 290 Australian adolescent students. The results showed that adolescents with high social anxiety scored significantly lower on learning and performance goals.

Conversely, individuals with social anxiety are afraid to allow themselves to be evaluated negatively by others, resulting in them having an image of themselves (selfpresentation) that is more positive than it really is, as they seek positive judgements from the people with whom they interact. In this sense, Banerjee and Watling (2010) found that self-presentation tactics in English children aged eight and nine were positively and significantly correlated with social anxiety, and that social anxiety was a positive predictor of the use of self-presentation tactics.

In addition, there are other studies that highlight the relationship between academic goals and internalising problems, anxiety and shyness. A study of 97 American and 238 Dutch individuals aged 12 to 14 (Roeser, Van der Wolf \& Strobel, 2001) showed that internalising problems such as withdrawal, anxiety and depression were negatively and significantly associated with self-esteem and with the intrinsic motivation towards learning.

Another study that analysed anxiety and its impact on school motivation in adolescents (Cury, Elliot, Sarrazin, Da Fonseca \& Rufo, 2002) in a sample of 90 French students aged 13 to 15 evidenced that anxiety was an aversive experience that significantly diminished learning and performance goals.

Finally, Quiamzade and Croizet (2007) noted that the interpersonal social comparison affects the degree of threat on self-esteem and the perception of competence, in turn influencing the individual's attitude towards studying, given that 
the attention they give to the performance of others distracts them from resolving tasks at hand, which ultimately determines academic performance.

\section{Learning Strategies and their Relationship to High Social Anxiety}

Learning strategies are actions based on students’ initiatives, and comprise sequences of controlled activities that play a mediating role in learning processes (González-Pienda, Núñez \& García-Rodríguez, 2006). In this sense, empirical evidence has emphasized the predictive power of learning strategies on students' academic achievement (Mckenzie, Gow \& Schweitzer, 2004).

Despite extensive and growing literature on this subject, no studies have analysed the relationship between learning strategies and social anxiety in adolescents; although Cantwell and Andrews (2002) did find that the symptomatology of social anxiety, specifically distress in familial social situations and avoidance of social interactions, was negatively and significantly correlated with knowledge of cognition in secondary school students. Therefore, adolescents with social anxiety were less aware of the types of learning strategies they developed.

In addition, a study of a sample of Norwegian primary and secondary school students aged 8 to 13 found a significant relationship between social anxiety and lack of concentration, persistence and impulsivity (Van Roy, Kristensen, Groholt \& ClenchAas, 2009). The authors note that these factors may be due to the attentional pathways that socially anxious adolescents use, often directed towards avoiding social threat instead of focusing on performing tasks.

\section{This Study}

A review of previous research concerning the relationships between social anxiety, learning strategies and academic motivation, besides being scarce, showed several gaps in this area. First, previous research has studied the relationship between 
academic goals and learning strategies to social anxiety, but ignored the predictive relationship between these variables in adolescents. Likewise, previous studies have not included effect sizes or magnitude of differences, making it impossible to interpret the theoretical and practical relevance of the results.

Considering these limitations, the present study has three objectives: a) to analyse the differences in academic goals and learning strategies among Spanish ESO (Obligatory Secondary Education) students with and without high social anxiety, b) to determine the extent to which high social anxiety predicts high academic goals and c) to determine the degree to which high social anxiety predicts the use of learning and study strategies.

Based on the findings from previous research, it is expected: 1) that students with high social anxiety present lower scores in academic goals compared to those with low social anxiety; 2) that students with high social anxiety use significantly less learning and study strategies compared to students without high social anxiety, except in the anxiety sub-scale where they will present more school anxiety than students with low social anxiety. In addition, by using logistic regression statistics, it is expected that: 3) high social anxiety will be a negative and significant predictor of academic goals; and 4) social anxiety will be a negative and significant predictor of study strategies, except school anxiety strategy, which will be a positive and significant predictor.

\section{Method}

\section{Participants}

A random sampling by clusters was carried out where the primary sampling units were the geographical zones (central, north, south, east and west) of Alicante and Murcia. The secondary units were the schools of each geographical area and, finally, the tertiary units were the classrooms. In order to ensure that all geographical areas were 
represented 20 centres were randomly selected from rural and urban areas, 14 public and six private. Each geographical area was represented by an average of two centres. Having determined the centres to be studied, four classrooms were randomly selected, calculating approximately 120 individuals per centre.

The total number of individuals registered was 2267 students, of which 116 (5.12\%) were excluded because of errors or omissions in their answers or failure to obtain parental consent to participate in the research as well as another 129 (5.69\%) because they were foreign and had a low proficiency level in Spanish.

The final sample consisted of 2022 students (52.1\% male and $47.9 \%$ female) with an age range of 12 to $16(M=13.81, S D=1.35)$. The distribution of the sample by academic year was: 1st year ESO (576; 309 males and 267 female), 2nd year ESO (505; 251 males and 254 females), 3rd year ESO (502; 260 males and 242 females) and 4th year ESO (439; 213 males and 226 females). The chi-square test of homogeneity of the frequency distribution evidenced the absence of statistically significant differences between the eight groups Sex x Year $\left(\chi^{2}=3.16 ; p=.37\right)$. The geographical composition of the sample was as follows: $88.9 \%$ Spanish, $6.34 \%$ Latin-American, $3.37 \%$ rest of Europe, 0.75\% Asian and 64\% Arab.

\section{Instruments}

\section{Social Phobia and Anxiety Inventory (SPAI; Turner, Beidel, Dancu \&}

Stanley, 1989)

The SPAI is a self-report measure composed of 32 items designed to assess the cognitive, physiological and motor symptomatology of social anxiety in adolescence. Each item is scored using a seven-point Likert scale $(1=$ never, $7=$ always $)$. The SPAI is one of the tools that best guarantees the psychometric assessment of social anxiety in the English and Spanish-speaking community adolescent population (García-López, De 
Los Reyes \& Salvador, 2015). The Spanish adaptation of the SPAI was made by Olivares, García-López, Hidalgo, Turner and Beidel (1999) through the translation and adaptation of the items for the adolescent population, obtaining evidence of their score's reliability and validity. The internal consistency of the instrument in this study was satisfactory $(\alpha=.95)$.

\section{Achievement Goal Tendencies Questionnaire (AGTQ; Hayamizu \& Weiner,} 1991)

The AGTQ assesses students' goal orientation in a school context. It consists of 20 items, grouped into three categories: Learning goals, individuals study with the intention of increasing their own skills; social reinforcement goals, individuals study with the purpose of obtaining approval from parents, teachers and peers and to avoid rejection, and achievement goals, individuals study in order to seem competent, or as a means of increasing the status of their capacity. Each item was scored using a five-point Likert scale (1 = never, 5 = always $)$.

The scores' evidence of reliability and validity for the Spanish version of the AGTQ was confirmed by Inglés et al. (2009). In addition, the results found by Inglés et al. (2011) supported the factorial invariance of the three-dimensional model of the questionnaire through sex and age. Cronbach's alpha coefficients in the present study were: .80 (Learning goals), .77 (Social Reinforcement goals) and .74 (Achievement goals).

\section{Learning and Studies Skills Inventory - High School Version (LASSI-HS;} Weinstein \& Palmer, 2002)

LASSI is an instrument widely used to assess the strategies and skills that students develop in academic contexts. It comprises 76 items in ten subscales. Attitude, Motivation, Time Management, Anxiety, Concentration, Information Processing, 
Selection of Main Ideas, Study Aid, Self-Assessment and Evaluation Strategies. The answer to each of the items is taken from a Likert scale ranging from 1 (always) to 5 (never). The reliability of the instrument has been confirmed by the original authors (Weinstein \& Palmer, 2002) and by Spanish researchers (Núñez, González-Pienda, García, González-Pumariega \& García, 1998). The internal consistency of the LASSI in this study was acceptable, ranging from .68 to .82 .

\section{Procedure}

An interview with the directors and educational psychologists of the participating centres were carried out to outline the objectives of the research study, describe the assessment tools, request the relevant permits and promote collaboration. Following that, a meeting was held with parents to explain the study and request active and written informed consent allowing their children to participate in the research. The tests were answered collectively and anonymously in the classroom at the end of the school year. Researchers were present during the tests to provide help if needed and verify independent completion by participants.

\section{Statistical Analysis}

The identification of students with and without social anxiety was established by the cut-off point proposed by Olivares et al. (2002). Thus, the overall sample $(N=2022)$ was divided into two groups: a) individuals with no social anxiety: scores less than 100 $\left(n_{1}=1778,87.94 \%\right)$ and; B) individuals with social anxiety: scores equal to or greater than $100\left(n_{2}=244,12.06 \%\right)$.

To analyse the differences in academic goals and learning strategies between students with low and high social anxiety, a Student's $t$ test was applied. Due to the high sample size of the study, the $t$-test can erroneously detect statistically significant differences. For this reason, we also included the index $d$ (typified mean difference) 
proposed by Cohen (1988), which allows us to evaluate the magnitude or the size of the effect of the differences found. Its interpretation is simple: $0.20 \leq d \leq 0.50$ is a small effect size, while $0.51 \leq d \leq 0.79$ is moderate effect size and $d \geq 0.80$ is a large effect size.

In order to examine and quantify the predictive capacity of social anxiety on academic goals and learning strategies, binary logistic regression analysis was performed following the forward step regression procedure based on the Wald statistic. Thus, the predictor variable (social anxiety) and criterion variables (academic goals and learning strategies) were dichotomized. The dichotomization used for social anxiety was the same one used for the analysis of mean differences, while the scores for each academic goal and learning strategy sub-scale were dichotomized as: a) low academic goals and learning strategies: scores equal to or lower than the 25th quantile and, b) high academic goals and learning strategies: scores equal to or higher than the 75th quantile.

Logistic modelling allows estimating the probability of an event or outcome (e.g., high learning goals) in the presence of one or more predictors (e.g., high social anxiety). This probability is estimated using the statistic called the odds ratio (OR). If the OR is greater than 1 , the increase of the independent variable is associated with an increase in the advantage of the event. On the contrary, if the OR is less than 1 , the increase of the independent variable leads to a decrease in the advantage of the event (De Maris, 2003).

\section{Results}

The Academic Goals and Learning Strategies of Students with and without High Anxiety 
The $t$-test for mean differences found no statistically significant difference in the goal orientations of students with and without high social anxiety (see Table 1). With regard to learning strategies, students with high social anxiety use significantly less time management, selection of main ideas and evaluation strategies. In addition, they concentrate less, have a worse attitude towards and estimation of school and present a higher level of school anxiety than students without social anxiety. The magnitude of these differences ranged from 0.15 to 0.55 , suggesting that they were of very small to moderate magnitude.

\section{High Social Anxiety as a Predictor of Academic Goals and Learning Strategies}

From the sample analysed we were able to create a logistic model for the prediction of academic goals based on high social anxiety. The predictive model for social reinforcement goals correctly estimates $53.6 \%$ of cases $\left(\chi^{2}=4.27, p=.04\right)$. The setting value of the model ( $\mathrm{R}^{2}$ Nagelkerke) was .01.

The OR of the model indicates that students with high social anxiety are 52\% more likely to maintain high social reinforcement goals, that is, they are more likely to study in order to avoid negative judgements from parents and teachers and to seek their social approval (see Table 2).

With regard to the prediction of learning strategies, six logistic models were created based on the social anxiety score (attitude, motivation, time management, anxiety, concentration, selection of main ideas and evaluation strategies).

The correct estimation of predictive model cases was as follows: time management 59.5\% $\left(\chi^{2}=4.22, p=.04\right)$, concentration 57.7\% $\left(\chi^{2}=24.73, p<.05\right)$, selection of main ideas $\left(\chi^{2}=14.14, p<.05\right)$, evaluation strategies $61.5 \%\left(\chi^{2}=25.87, p\right.$ $<.05)$, attitude towards school 54.4\% $\left(\chi^{2}=13.75, p<.05\right)$, motivation 54\% $\left(\chi^{2}=4.37, p\right.$ $=.04)$ and school anxiety 58\% $\left(\chi^{2}=45.93, p<.05\right)$. The adjustment value of the models 
( $\mathrm{R}^{2}$ Nagelkerke) ranged from .01 for the motivation and time management models and .06 for the anxiety model.

The ORs of the logistic models for the prediction of the use of learning and study strategies (see Table 2) suggest that students with high social anxiety: are $48 \%$ less likely to present an adequate attitude towards school and learning; have a 32\% lower probability of being motivated to accomplish school tasks; have a 33\% lower probability of correctly managing their study time; are $71 \%$ more likely to have high anxiety and worry in school; are 61\% less likely to maintain high concentration during academic tasks; have a 50\% lower probability of frequently using a selection of main ideas strategy and have a 61\% lower probability of using an evaluation strategy.

\section{Discussion}

The present study had three objectives. The first was to analyse the differences in academic goals and learning strategies among ESO students with and without high social anxiety, the second was to determine the extent to which high social anxiety predicts high academic goals and the third was to analyse to what degree high social anxiety predicts the use of learning and study strategies.

Contrary to what was expected in the first hypothesis, the results did not reveal statistically significant differences in academic goals between students with and without high social anxiety; thus the findings of the study do not support the conclusions drawn by Cantwell and Andrews (2002). From these findings, we can conclude that individuals with high social anxiety may seek study goals similar to those without high social anxiety, although, because they have a low perception of their own competence, they may feel less able to achieve them (Delgado et al., 2013).

Given the relationship between high social anxiety and learning strategies, the results partially confirm the second hypothesis. That is, the data show that students with 
high social anxiety use less time management, selection of main ideas and evaluation strategies. In addition, they concentrate less, have a worse attitude towards and estimation of school and present a higher level of school anxiety in the school context. These findings are in line with studies indicating that individuals with social anxiety implement less self-regulation strategies during school tasks (Cantwell \& Andrews, 2002), concentrate less and are less persistent in tasks (Van Roy et al. 2009).

However, students with high social anxiety carry out similar information processing and self-assessment strategies and use study aids for school tasks as often as students without high social anxiety. Thus, according to cognitive models of social anxiety, socially anxious individuals tend to focus their attention on the evaluation of their own social performance (Rapee \& Heimberg, 1997) with the intention of assessing their competence.

As expected, this study found that students with high social anxiety show a higher level of school anxiety towards school than students with low social anxiety. These results confirm what has been concluded in previous studies on social anxiety and school phobia (Egger, Costello \& Angold, 2003), in which an ample relationship between the degree of social anxiety and fear towards school was found.

High social anxiety was a positive and significant predictor of social recognition goals, that is, students with high social anxiety are more likely to focus on social approval, which partially confirms the third hypothesis. In the same vein, Banerjee and Watling (2010) found that children with social anxiety tended to have an image of themselves (self-presentation) that is more positive than it really is, as they seek positive judgements from the people with whom they interact, given that they fear being evaluated and judged negatively by others. In addition, according to Quiamzade and Croizet (2007), social comparison affects the individual's self-esteem and perception of 
their own competence and this, in turn, influences the individual's attitude towards studying, given that the attention they give to the performance of others distracts them from resolving tasks at hand, which ultimately determines academic performance.

In addition, secondary school students who have high social recognition goals are less likely to achieve high mathematics and language scores or a high general performance level than individuals with a low focus on social approval (Inglés et al., 2009). Therefore, although students with high social anxiety present similar academic goals to students with low social anxiety, it is probable that their predisposition to focus their learning on being accepted and not rejected by parents and teachers makes them susceptible to lower school marks (Delgado et al., 2014).

According to the fourth hypothesis, high social anxiety was a significant predictor of learning strategies. Thus, students with social anxiety were less likely to have an positive attitude towards school and learning, be motivated to accomplish school tasks, manage their study time correctly, maintain a high concentration during academic tasks, frequently use a selection of main ideas strategy and manage effective evaluation strategies. In addition, students with high social anxiety were more likely to experience high anxiety and worry at school. These findings point again to the low appreciation students with high social anxiety have for school, the tension and nervousness they suffer in the classroom, as well as the deficit in the use of study selfregulation strategies.

This research has some limitations. First, although the sample used guarantees a wide representation of the target population, future research should confirm whether these results found in Spanish ESO differ or are maintained for other educational levels and other cultures/ethnicities. Second, establishing generalisations of these findings for Spanish ESO students diagnosed with learning or psychopathological disorders, or any 
aspects that may alter the social and academic behaviour of students would not be appropriate. In addition, because we cannot strictly speak of individuals “with” or "without” social anxiety in the absence of a clinical diagnosis, we can only use the terms individuals with "high" or "low" social anxiety. This is why the high percentage of individuals that exceed the cut-off point (12\%) is similar to other studies that have administered these scales, but significantly lower than when clinical samples are available (about 5\%) (Knappe, Sagagawa \& Creswell , 2015). Finally, social anxiety has been assessed only through the sub-clinical cut-off point of a self-report. Thus, future research should include information derived from clinical interviews and provided by other agents such as parents and teachers.

At a practical level, and considering that various research studies have pointed to academic motivation and strategies as relevant factors in predicting academic achievement, these cognitive-motivational factors should be considered when designing strategies for preventing school failure and early school abandonment by adolescents with high social anxiety. 
Table 1

Differences in academic goals and learning strategies between students with and without high social anxiety

\begin{tabular}{|c|c|c|c|c|c|}
\hline & \multirow{2}{*}{$\begin{array}{c}\text { Low Social } \\
\text { Anxiety } \\
M(S D)\end{array}$} & \multirow{2}{*}{$\begin{array}{l}\text { High Social } \\
\text { Anxiety } \\
M(S D)\end{array}$} & \multicolumn{3}{|c|}{$\begin{array}{l}\text { Statistical significance } \\
\text { and magnitude of } \\
\text { differences }\end{array}$} \\
\hline & & & $t$ & $p$ & $d$ \\
\hline \multicolumn{6}{|l|}{ Academic goals } \\
\hline Learning goals & $30.51(5.65)$ & 30.20 (5.73) & 0.80 & n.s. & - \\
\hline Achievement goals & 25.58 (3.74) & 25.38 (3.87) & 0.78 & n.s. & - \\
\hline Social reinforcement goals & $20.54(5.48)$ & $21.14(5.17)$ & -1.63 & n.s. & - \\
\hline \multicolumn{6}{|l|}{ Learning strategies } \\
\hline Attitude & $29.15(5.55)$ & $27.41(5.95)$ & 4.55 & .00 & 0.31 \\
\hline Motivation & $29.62(5.61)$ & $28.87(5.81)$ & 1.95 & n.s. & - \\
\hline Time management & $21.77(4.11)$ & $21.17(4.10)$ & 2.16 & .03 & 0.15 \\
\hline Anxiety & $21.51(5.24)$ & $18.60(5.61)$ & 8.06 & .00 & 0.55 \\
\hline Concentration & 27.07 (5.89) & $24.78(6.48)$ & 5.62 & .00 & 0.38 \\
\hline Information processing & $25.92(5.13)$ & $26.20(5.51)$ & -0.81 & n.s. & - \\
\hline Selection of main ideas & $17.90(3.44)$ & $16.94(3.45)$ & 4.08 & .00 & 0.28 \\
\hline Study aids & 23.37 (5.09) & $23.88(5.43)$ & -1.45 & n.s. & - \\
\hline Self-assessment & 25.65 (4.98) & $25.80(5.27)$ & -0.44 & n.s. & - \\
\hline Evaluation strategies & $28.51(5.39)$ & $26.07(5.92)$ & 6.57 & .00 & 0.45 \\
\hline
\end{tabular}

Note. n.s. = not significant. 
Table 2

Results derived from binary logistic regression for the probability of presenting high scores in academic goals and in learning strategies

\begin{tabular}{|c|c|c|c|c|c|c|c|}
\hline & & $\mathrm{B}$ & $\mathrm{SE}$ & Wald & $p$ & OR & CI 95\% \\
\hline \multicolumn{8}{|l|}{ Academic goals } \\
\hline Social reinforcement goals & High Social Anxiety & 0.42 & 0.20 & 4.17 & .04 & 1.52 & $1.02-2.26$ \\
\hline \multicolumn{8}{|l|}{ Learning strategies } \\
\hline \multirow[t]{2}{*}{ Attitude } & High Social Anxiety & -0.66 & 0.18 & 13.31 & .00 & 0.52 & $0.36-0.74$ \\
\hline & Constant & 0.13 & 0.06 & 3.88 & .05 & 1.13 & \\
\hline \multirow[t]{2}{*}{ Motivation } & High Social Anxiety & -0.39 & 0.19 & 4.34 & .04 & 0.68 & $0.47-0.98$ \\
\hline & Constant & 0.15 & 0.07 & 5.01 & .03 & 1.16 & \\
\hline \multirow[t]{2}{*}{ Time management } & High Social Anxiety & -0.40 & 0.19 & 4.24 & .04 & 0.67 & $0.46-0.98$ \\
\hline & Constant & 0.43 & 0.07 & 41.73 & .00 & 1.54 & \\
\hline \multirow[t]{2}{*}{ Anxiety } & High Social Anxiety & -1.24 & 0.19 & 40.92 & .00 & 0.29 & $0.20-0.42$ \\
\hline & Constant & 0.20 & 0.07 & 8.67 & .00 & 1.23 & \\
\hline \multirow[t]{2}{*}{ Concentration } & High Social Anxiety & -0.95 & 0.20 & 23.31 & .00 & 0.39 & $0.26-0.57$ \\
\hline & Constant & 0.26 & 0.07 & 14.43 & .00 & 1.29 & \\
\hline \multirow[t]{2}{*}{ Selection of main ideas } & High Social Anxiety & -0.70 & 0.19 & 13.82 & .00 & 0.50 & $0.35-0.72$ \\
\hline & Constant & 0.29 & 0.06 & 20.31 & .00 & 1.34 & \\
\hline \multirow[t]{2}{*}{ Evaluation strategies } & High Social Anxiety & -0.95 & 0.19 & 24.99 & .00 & 0.39 & $0.27-0.56$ \\
\hline & Constant & 0.47 & 0.07 & 45.92 & .00 & 1.60 & \\
\hline
\end{tabular}

Note. $\mathrm{B}$ = coefficient; $\mathrm{SE}$ = Standard Error; $\mathrm{P}$ = Probability; $\mathrm{OR}=$ Odds Ratio; $\mathrm{CI}=$ Confidence Interval $95 \%$ 


\section{Metas académicas y estrategias de aprendizaje en estudiantes españoles de Educación Secundaria Obligatoria con ansiedad social}

La ansiedad social se caracteriza por un miedo intenso y persistente a una o más situaciones sociales en las cuales la persona está expuesta a gente no familiar, o al posible análisis de otros (APA, 2013). Es una problemática de prevalencia moderada, que suele iniciarse durante la adolescencia temprana y que genera una interferencia considerable sobre el ajuste académico y el desarrollo social de los menores. Así, el alto absentismo, la escasa participación en clase, o la tendencia a evitar preguntar al profesor (Bernstein, Bernat, Davis y Layne, 2008) contribuyen a que el estudiante ansioso no pueda contrastar sus aprendizajes y obtenga calificaciones académicas más bajas (Delgado, Inglés y García-Fernández, 2014). Igualmente, la evitación de las relaciones con los compañeros genera una baja aceptación en el grupo de iguales (Inglés, Delgado, García-Fernández, Ruiz-Esteban y Díaz-Herrero, 2010), así como una percepción negativa del adolescente hacia sí mismo (Delgado, Inglés y García-Fernández, 2013) y hacia la escuela. No obstante, poco se sabe sobre el modo en que los estudiantes con ansiedad social autorregulan su aprendizaje. Este estudio tiene como objetivo analizar las metas académicas y el uso de estrategias de aprendizaje de los adolescentes con ansiedad y dificultades para relacionarse socialmente.

\section{Las Metas Académicas y su Relación con la Alta Ansiedad Social}

Las metas pueden ser definidas como un patrón integrado de pensamientos y razones de las conductas que los individuos mantienen en un contexto de logro (Linnenbrink y Pintrich, 2000). La importancia de las orientaciones de meta reside en que son elementos altamente relacionados con el autoconcepto (Inglés et al., 2015), la efectividad en el procesamiento de la información y la persistencia en la tarea, los cuales repercuten sobre el rendimiento escolar. 
La relación de la ansiedad social con las metas académicas en estudiantes de secundaria ha sido analizada escasamente. En este sentido, Cantwell y Andrews (2002) analizaron la relación entre el interés y las metas motivacionales, la conciencia metacognitiva, la necesidad de afiliación, los sentimientos en el grupo de trabajo y la ansiedad social en una muestra de 290 estudiantes adolescentes australianos. Los resultados reflejaron que los adolescentes con puntuaciones elevadas en ansiedad social alcanzaban puntuaciones significativamente menores en metas de aprendizaje y de rendimiento.

Por otra parte, los sujetos con ansiedad social temen ser evaluados negativamente por los demás, lo que hace que se orienten a dar una imagen de sí mismos (autopresentación) más positiva que real, con la intención de buscar juicios positivos de las personas con quienes interactúan. En este sentido, Banerjee y Watling (2010) encontraron en niños ingleses de 8 y 9 años, que las tácticas de autopresentación se relacionaban positiva y significativamente con la ansiedad social, y que la ansiedad social era un predictor positivo del uso de tácticas de autopresentación.

Además existen otros trabajos que señalan la relación entre las metas académicas y los problemas internalizantes, la ansiedad y la timidez. Así lo destaca un estudio realizado con muestras de 97 estadounidenses y 238 holandeses de 12 a 14 años (Roeser, Van der Wolf y Strobel, 2001) que reveló que los problemas internalizantes como el retraimiento, la ansiedad y la depresión se relacionaban negativa y significativamente con la autoestima y con la motivación intrínseca hacia el aprendizaje. Posteriormente, un trabajo que analizó la ansiedad rasgo y su repercusión sobre la motivación escolar en adolescentes (Cury, Elliot, Sarrazin, Da Fonseca y Rufo, 2002) en una muestra de 90 estudiantes franceses de 13 a 15 años, reveló que la ansiedad 
rasgo suponía una experiencia aversiva que mermaba, de forma significativa, las metas de aprendizaje y de rendimiento.

Finalmente, Quiamzade y Croizet (2007) señalan que la comparación social interpersonal incide sobre el grado de amenaza en la autoestima y en la percepción de competencia y ésta, a su vez, sobre la manera de orientarse hacia el estudio, ya que la atención focalizada en el desempeño de los otros distrae la solución de las tareas, que determina finalmente el rendimiento académico.

\section{Las Estrategias de Aprendizaje y su Relación con la Alta Ansiedad Social}

Las estrategias de aprendizaje son acciones que parten de la iniciativa del alumno, y están constituidas por secuencias de actividades controladas que cumplen una función mediadora en los procesos de aprendizaje (González-Pienda, Núñez y GarcíaRodríguez, 2006). En este sentido, la evidencia empírica ha subrayado el poder predictivo de las estrategias de aprendizaje sobre el éxito académico de los estudiantes (Mckenzie, Gow y Schweitzer, 2004).

A pesar de la extensa y creciente literatura sobre este tema, no se han encontrado investigaciones que analicen la relación entre estrategias de aprendizaje y la ansiedad social en adolescentes. Si bien, Cantwell y Andrews (2002) encontraron que la sintomatología de ansiedad social, concretamente la angustia en situaciones sociales familiares y la evitación de interacciones sociales, se relacionaba negativa y significativamente con el conocimiento de la cognición en estudiantes de secundaria. Por tanto, los adolescentes con ansiedad social eran menos conscientes del tipo de estrategias de aprendizaje que desarrollaban.

Además, un estudio elaborado con una muestra de estudiantes noruegos de primaria y secundaria de 8 a 13 años, halló una relación significativa entre ansiedad social y la falta de concentración, de persistencia e impulsividad (Van Roy, Kristensen, 
Groholt y Clench-Aas, 2009). Los autores señalan que estos factores pueden deberse a las vías atencionales que mantienen los ansiosos sociales, dirigidos hacia la evitación de la amenaza social más que a la ejecución de tareas.

\section{El Presente Estudio}

La revisión de la investigación previa relativa a las relaciones entre ansiedad social, estrategias de aprendizaje y motivación académica, además de ser escasa, presenta varias limitaciones. En primer lugar, investigaciones anteriores han estudiado la relación de las metas académicas y estrategias de aprendizaje con la ansiedad social pero sin contemplar la relación predictiva entre las variables en adolescentes. Asimismo, los estudios previos tampoco han incluido los tamaños del efecto o magnitud de las diferencias, lo que imposibilita interpretar la relevancia teórica y práctica de los resultados.

Teniendo en cuenta estas limitaciones, el presente estudio tiene tres objetivos: a) analizar las diferencias en metas académicas y estrategias de aprendizaje entre estudiantes de ESO con y sin alta ansiedad social, b) determinar en qué medida la alta ansiedad social pronostica las altas metas académicas, y c) determinar en qué grado la alta ansiedad social predice el uso de las estrategias de aprendizaje y estudio.

A partir de los hallazgos de investigaciones previas, se espera: 1) que los estudiantes con alta ansiedad social respecto a aquellos con baja ansiedad social presenten puntuaciones inferiores en las metas académicas; 2) que los estudiantes con alta ansiedad social utilicen significativamente menos estrategias de aprendizaje y estudio en comparación con los estudiantes sin alta ansiedad social, excepto en la subescala de ansiedad en la que presentarán más ansiedad escolar que los estudiantes con baja ansiedad social. Además, a través de los estadísticos de regresión logística, se espera que: 3) la alta ansiedad social sea un predictor negativo y significativo de las 
metas académicas; y 4) la ansiedad social sea un predictor negativo y significativo de las estrategias de estudio, menos la estrategia de ansiedad escolar que será un predictor positivo y significativo.

\section{Método}

\section{Participantes}

Se realizó un muestreo aleatorio por conglomerados, siendo las unidades primarias de muestreo las zonas geográficas (centro, norte, sur, este y oeste) de Alicante y Murcia. Las unidades secundarias fueron los centros escolares de cada zona geográfica y, finalmente, las unidades terciarias fueron las aulas. Con el fin de que todas las zonas geográficas estuvieran representadas se seleccionaron aleatoriamente 20 centros de áreas rurales y urbanas, 14 públicos y 6 privados. Cada zona geográfica estuvo representada por una media de dos centros. Una vez determinados los centros del estudio, se seleccionaron aleatoriamente cuatro aulas computándose aproximadamente 120 sujetos por centro.

El total de sujetos seleccionados fue 2267, de los que 116 (5.12\%) fueron excluidos por errores u omisiones en sus respuestas o por no obtener por escrito el consentimiento informado de los padres para participar en la investigación y 129 (5.69\%) fueron excluidos por ser extranjeros con importantes déficits en el dominio de la lengua española.

La muestra final se compuso de 2022 estudiantes (1033 varones y 989 mujeres) de ESO, con un rango de edad de 12 a 16 años $(M=13.81 ; D T=1.35)$. La distribución de la muestra por curso académico fue la siguiente: $1^{\circ}$ ESO (576; 309 varones y 267 mujeres), $2^{\circ}$ ESO (505; 251 varones y 254 mujeres), $3^{\circ}$ ESO (502; 260 varones y 242 mujeres) y $4^{\circ}$ de ESO (439; 213 varones y 226 mujeres). La prueba chi-cuadrado de homogeneidad de la distribución de frecuencias reveló la ausencia de diferencias 
estadísticamente significativas entre los ocho grupos de Sexo $\mathrm{x}$ Curso $\left(\chi^{2}=3.16 ; p=\right.$ .37). La composición geográfica de la muestra fue la siguiente: $88.9 \%$ españoles, $6.34 \%$ hispanoamericanos, 3.37\% resto Europa, .75\% asiáticos y .64\% árabes.

\section{Instrumentos}

\section{Social Phobia and Anxiety Inventory (SPAI; Turner, Beidel, Dancu y}

\section{Stanley, 1989)}

El SPAI es una medida de autoinforme compuesta por 32 ítems, diseñada para evaluar la sintomatología cognitiva, la fisiológica y la motora de la ansiedad social en la adolescencia. Cada ítem se puntúa según una escala Likert de siete puntos ( 1 = nunca; 7 $=$ siempre). El SPAI es una de las herramientas con mejores garantías psicométricas para examinar la ansiedad social en población comunitaria adolescente anglo e hispanoparlante (García-López, De Los Reyes y Salvador, 2015). La adaptación española del SPAI fue realizada por Olivares, García-López, Hidalgo, Turner y Beidel (1999) a través de la traducción y adecuación de los ítems para población adolescente, obteniendo evidencias de fiabilidad y validez de sus puntuaciones. La consistencia interna del instrumento en este estudio fue satisfactoria $(\alpha=.95)$.

\section{Achievement Goal Tendencies Questionnaire (AGTQ; Hayamizu y Weiner,} 1991)

El AGTQ evalúa las orientaciones de meta de los estudiantes en el ámbito escolar. Consta de 20 ítems, agrupados en tres factores: Metas de aprendizaje, los sujetos estudian con la intención de aumentar su propia competencia, Metas de reforzamiento social, sujetos estudian con el propósito de obtener aprobación por parte de padres, profesores y compañeros y evitar su rechazo, y Metas de logro, los sujetos estudian con la intención de no parecer incompetente, o como medio de aumentar el 
estatus de la propia capacidad. Los ítems son valorados mediante en una escala Likert de 5 puntos $(1$ = nunca; 5 = siempre $)$.

La evidencia de fiabilidad y validez de las puntuaciones de la versión española del AGTQ fue confirmada por Inglés et al. (2009). Asimismo, los resultados hallados por Inglés et al. (2011) apoyaron la invarianza factorial del modelo tridimensional del cuestionario a través del sexo y la edad. Los coeficientes alfa de Cronbach en el presente estudio fueron: .80 (Metas de aprendizaje), .77 (Metas de reforzamiento social) y .74 (Metas de logro).

\section{Learning and Studies Skills Inventory-High School (LASSI-HS; Weinstein y}

\section{Palmer, 2002)}

El LASSI es un instrumento extensamente utilizado para evaluar las estrategias y las habilidades que desarrollan los estudiantes en contextos académicos. Está compuesto por 76 ítems agrupados en diez subescalas: Actitud, Motivación, Gestión del Tiempo, Ansiedad, Concentración, Procesamiento de la Información, Selección de ideas principales, Ayuda al Estudio, Autoevaluación y Estrategias de evaluación. La respuesta a cada uno de los ítems se realiza a partir de una escala Likert que oscila de 1 (siempre) a 5 (nunca). La fiabilidad del instrumento ha sido confirmada por los autores originales (Weinstein y Palmer, 2002) y por investigadores españoles (Núñez, González-Pienda, García, González-Pumariega y García, 1998). La consistencia interna del LASSI en este estudio fue aceptable, oscilando entre .68 y .82.

\section{Procedimiento}

Se llevó a cabo una entrevista con los directores y psicopedagogos de los centros participantes para exponer los objetivos del estudio, describir los instrumentos, solicitar los permisos pertinentes y promover su colaboración. Posteriormente, se celebró una reunión con los padres para explicarles el estudio y solicitar el consentimiento activo e 
informado por escrito, autorizando a sus hijos a participar en la investigación. Las pruebas fueron contestadas de forma colectiva y anónima en el aula a finales del curso escolar. Los investigadores estuvieron presentes durante la administración de las pruebas para proporcionar ayuda si era necesaria y verificar la cumplimentación independiente por parte de los participantes.

\section{Análisis Estadísticos}

La identificación de estudiantes con y sin ansiedad social se estableció a partir del punto de corte propuesto por Olivares et al. (2002). Así, la muestra general ( $N=$ 2022) se dividió en dos grupos: a) sujetos sin ansiedad social: puntuaciones inferiores a 100 ( $\left.n_{1}=1778 ; 87.94 \%\right)$ y; b) sujetos con ansiedad social: puntuaciones iguales o superiores a $100\left(n_{2}=244 ; 12.06 \%\right)$.

Para analizar las diferencias en metas académicas y estrategias de aprendizaje entre estudiantes con baja y alta ansiedad social se aplicó la prueba $t$ de Student. Debido al elevado tamaño muestral del estudio, la prueba $t$ puede detectar erróneamente diferencias estadísticamente significativas. Por esta razón se incluye, además, el índice $d$ (diferencia media tipificada) propuesto por Cohen (1988), que permite valorar la magnitud o el tamaño del efecto de las diferencias encontradas. Su interpretación es sencilla: $.20 \leq d \leq .50$ supone un tamaño del efecto pequeño, mientras que $.51 \leq d \leq .79$ es moderado y $d \geq .80$ es grande.

Con el fin de examinar y cuantificar la capacidad predictiva de la ansiedad social sobre las metas académicas y las estrategias de aprendizaje, se llevaron a cabo análisis de regresión logística binaria siguiendo el procedimiento de regresión por pasos hacia delante basado en el estadístico de Wald. Así, la variable predictora (ansiedad social) y las variables criterio (metas académicas y estrategias de aprendizaje) fueron dicotomizadas. Para la ansiedad social se mantuvo la misma dicotomización que para 
los análisis de diferencias de medias, mientras que las puntuaciones de cada subescala de las metas académicas y las estrategias de aprendizaje fueron dicotomizadas como: a) bajas metas académicas y estrategias de aprendizaje: puntuaciones iguales o inferiores al centil 25 y, b) altas metas académicas y estrategias de aprendizaje: puntuaciones iguales o superiores al centil 75.

El modelado logístico permite estimar la probabilidad de que ocurra un evento, suceso o resultado (e.g., altas metas de aprendizaje) en presencia de uno o más predictores (e.g., alta ansiedad social). Esta probabilidad es estimada mediante el estadístico denominado odd ratio (OR). Si la OR es mayor que 1 el aumento de la variable independiente lleva asociado un aumento en la ventaja del suceso. Por el contrario, si la OR es menor que 1 el aumento de la variable independiente conlleva una disminución de la ventaja del suceso (De Maris, 2003).

\section{Resultados}

\section{Metas Académicas y Estrategias de Aprendizaje de Estudiantes con y sin Alta}

\section{Ansiedad Social}

La prueba $t$ de diferencias entre medias no halló ninguna diferencia estadísticamente significativa en las orientaciones de meta entre estudiantes con y sin alta ansiedad social (véase Tabla 1). Respecto a las estrategias de aprendizaje, los estudiantes con alta ansiedad social utilizan significativamente menos estrategias de gestión del tiempo, de selección de ideas principales y de evaluación. Además, se concentran menos, mantienen una peor actitud y valor hacia la escuela y presentan un nivel más elevado de ansiedad escolar que los estudiantes sin ansiedad social. La magnitud de dichas diferencias osciló entre .15 y .55, lo que sugiere que fueron de muy pequeña a moderada magnitud. 


\section{La Alta Ansiedad Social como Predictora de las Metas Académicas y de las}

\section{Estrategias de Aprendizaje}

A partir de la muestra analizada fue posible crear un modelo logístico para la predicción de las metas académicas a partir de la alta ansiedad social. El modelo predictivo para las metas de refuerzo social permite una estimación correcta del 53.6\% de los casos $\left(\chi^{2}=4.27 ; p=.04\right)$. El valor de ajuste del modelo $\left(\mathrm{R}^{2}\right.$ Nagelkerke $)$ fue .01 .

La OR del modelo indica que los estudiantes con alta ansiedad social tienen un 52\% más de probabilidad de mantener altas metas de refuerzo social, o sea, que tienen más probabilidad de estudiar con el objetivo de evitar juicios negativos de padres y profesores y buscar la aprobación social de los mismos (véase Tabla 2).

Respecto a la predicción de las estrategias de aprendizaje, se crearon seis modelos logísticos (actitud, motivación, gestión del tiempo, ansiedad, concentración, selección de ideas principales y estrategias de evaluación) a partir de la puntuación de ansiedad social.

La estimación correcta de los casos de modelos predictivos fue la siguiente: gestión del tiempo 59.5\% $\left(\chi^{2}=4,22 ; p=.04\right)$, concentración 57.7\% $\left(\chi^{2}=24.73 ; p<\right.$ $.05)$, selección de ideas principales 57.5\% $\left(\chi^{2}=14.14 ; p<.05\right)$, estrategias de evaluación $61.5 \%\left(\chi^{2}=25.87 ; p<.05\right)$, actitud hacia la escuela 54.4\% $\left(\chi^{2}=13.75 ; p<\right.$ $.05)$, motivación 54\% $\left(\chi^{2}=4.37 ; p=.04\right)$ y ansiedad escolar 58\% $\left(\chi^{2}=45.93 ; p<.05\right)$. El valor de ajuste de los modelos $\left(\mathrm{R}^{2}\right.$ Nagelkerke) osciló entre .01 para los modelos de motivación y gestión del tiempo y .06 para el modelo de ansiedad.

Las OR de los modelos logísticos para la predicción del uso de estrategias de aprendizaje y estudio (véase Tabla 2) apuntan que los estudiantes con alta ansiedad social presentan un $48 \%$ menos de probabilidad de presentar una adecuada actitud hacia la escuela y el aprendizaje; un 32\% menos de probabilidad de estar motivado y 
orientado hacia la consecución de las tareas escolares; un 33\% menos de probabilidad de gestionar correctamente su tiempo de estudio; un 71\% más de probabilidad de tener alta ansiedad y preocupación en la escuela; un 61\% menos de probabilidad de mantener una alta concentración durante las tareas académicas; un 50\% menos de probabilidad de utilizar frecuentemente la estrategia de selección de ideas principales y un 61\% menos de probabilidad de manejar estrategias de evaluación.

\section{Discusión}

El presente estudio tuvo tres objetivos. En primer lugar, analizar las diferencias en metas académicas y las estrategias de aprendizaje entre estudiantes españoles de ESO con y sin alta ansiedad social, en segundo lugar, determinar en qué medida la alta ansiedad social pronostica altas metas académicas, y en tercer lugar, analizar en qué grado la alta ansiedad social predice el uso de las estrategias de aprendizaje.

Contrariamente a lo esperado en la primera hipótesis, los resultados no revelaron diferencias estadísticamente significativas en las metas académicas entre estudiantes con y sin alta ansiedad social, por tanto, no permiten apoyar las conclusiones obtenidas en el trabajo de Cantwell y Andrews (2002). A partir de estos hallazgos, podemos considerar que los individuos con alta ansiedad social pueden buscar metas de estudio comparables a la gente sin alta ansiedad social, si bien, al presentar una baja percepción de competencia pueden sentirse menos capaces de lograrlas (Delgado et al., 2013).

Atendiendo a la relación entre alta ansiedad social y estrategias de aprendizaje, los resultados confirman parcialmente la segunda hipótesis. Así, los datos señalan que los estudiantes con alta ansiedad social utilizan menos estrategias de gestión del tiempo, de selección de ideas principales y de evaluación. Además se concentran menos, mantienen una peor actitud y valor hacia la escuela y presentan un nivel más elevado de ansiedad en el entorno escolar. Estos hallazgos siguen la línea de trabajos que indican 
que los sujetos con ansiedad social ponen en marcha menores estrategias de autorregulación en tareas escolares (Cantwell y Andrews, 2002), se concentran menos y son menos persistentes en las tareas (Van Roy et al., 2009).

Sin embargo, los estudiantes con alta ansiedad social llevan a cabo un procesamiento de la información similar y utilizan estrategias de ayuda al estudio y de autoevaluación en tareas escolares con la misma frecuencia que los estudiantes sin alta ansiedad social. Así, según los modelos cognitivos de la ansiedad social, los sujetos socialmente ansiosos suelen focalizar su atención hacia la evaluación del propio desempeño social (Rapee y Heimberg, 1997) con la intención de valorar su competencia.

Conforme a lo esperado, este estudio comprobó que los estudiantes con alta ansiedad social presentan más nivel de ansiedad escolar hacia la escuela que los estudiantes con baja ansiedad social. Estos resultados confirman lo hallado en estudios previos sobre ansiedad social y fobia escolar (Egger, Costello y Angold, 2003), en los que se encontró una amplia relación entre el grado de ansiedad social y el miedo hacia la escuela.

La alta ansiedad social fue un predictor positivo y significativo de las metas de reconocimiento social, es decir, los estudiantes con alta ansiedad social tienen más probabilidad de orientarse hacia la aprobación social, lo que confirma parcialmente la tercera hipótesis. En esta línea, Banerjee y Watling (2010) hallaron que los niños con ansiedad social suelen orientarse a dar una imagen de sí mismos (autopresentación) más positiva que real, con la intención de buscar juicios positivos de las personas con quienes interactúan, ya que temen ser evaluados y juzgados negativamente por los demás. Además, según Quiamzade y Croizet (2007), la comparación social influye sobre la autoestima y en la percepción de la propia competencia y éstas, a su vez, en la 
forma de orientarse hacia el estudio, ya que la atención focalizada sobre el desempeño de los otros distrae la solución de las tareas, que influye finalmente en el rendimiento académico.

Además, los alumnos de secundaria que presentan altas metas de reconocimiento social tienen menos probabilidad de alcanzar altas calificaciones en matemáticas y lengua y un alto rendimiento general que los sujetos con una orientación baja hacia la aprobación social (Inglés et al., 2009). Por tanto, y a pesar de que los estudiantes con alta ansiedad social presenten metas académicas similares a los estudiantes con baja ansiedad social, es probable que su predisposición a orientar sus aprendizajes a ser aceptados y no ser rechazados por padres y profesores les haga susceptibles a obtener peores resultados escolares (Delgado et al., 2014).

Conforme a la cuarta hipótesis, la alta ansiedad social fue una variable predictora significativa de las estrategias de aprendizaje. Así, los estudiantes con ansiedad social presentaron menos probabilidad de mantener una adecuada actitud hacia la escuela y el aprendizaje, de estar motivados y orientados hacia la consecución de las tareas escolares, de gestionar correctamente su tiempo de estudio, de mantener una alta concentración durante las tareas académicas, de utilizar frecuentemente la estrategia de selección de ideas principales y de manejar estrategias de evaluación eficaces. Además, los estudiantes con alta ansiedad social tuvieron más probabilidad de presentar una alta ansiedad y preocupación en la escuela. Estos hallazgos apuntan nuevamente el bajo aprecio que tienen los alumos con alta ansiedad social por la escuela, la tensión y nerviosismo que sufren en el aula, así como el déficit en el uso de estrategias de autorregulación del estudio.

Esta investigación presenta algunas limitaciones. En primer lugar, aunque el muestreo empleado garantiza la representatividad de la muestra reclutada respecto a la 
población diana, futuras investigaciones deberían confirmar si los resultados hallados en ESO difieren o se mantienen en otros niveles educativos y en otras culturas/etnias. En segundo lugar, tampoco resultaría adecuado establecer generalizaciones de los hallazgos a estudiantes españoles de ESO diagnosticados con trastornos del aprendizaje o psicopatológicos, aspectos que pueden alterar el comportamiento social y académico de los estudiantes. Por otra parte, en este estudio no se puede hablar de sujetos “con" o "sin” ansiedad social estrictamente, sino de sujetos con alta o baja ansiedad social en ausencia de un diagnóstico clínico. Por ello, el elevado porcentaje de sujetos que superan el punto de corte (12\%) es similar al de otros estudios tras la administración de escalas pero significativamente inferior cuando se cuenta con muestras clínicas (alrededor del 5\%) (Knappe, Sagagawa y Creswell, 2015). Finalmente, la ansiedad social ha sido valorada únicamente mediante el punto de corte subclínico de un autoinforme. Por ello, futuras investigaciones deberían incluir la información derivada de entrevistas clínicas y de la aportada por otros agentes de información como padres y profesores.

A nivel práctico, y considerando que diversas investigaciones han señalado a la motivación académica y las estrategias como factores relevantes en la predicción del rendimiento académico, debería tenerse en cuenta estos factores cognitivomotivacionales en la prevención del fracaso escolar y el abandono prematuro de los estudios de los adolescentes con alta ansiedad social. 
Tabla 1

Diferencias de metas académicas y estrategias de aprendizaje entre estudiantes con y sin alta ansiedad social

\begin{tabular}{|c|c|c|c|c|c|}
\hline & \multirow{2}{*}{$\begin{array}{c}\text { Baja } \\
\text { Ansiedad } \\
\text { Social } \\
M(D T)\end{array}$} & \multirow{2}{*}{$\begin{array}{c}\text { Alta } \\
\text { Ansiedad } \\
\text { social } \\
M(D T)\end{array}$} & \multicolumn{3}{|c|}{$\begin{array}{c}\text { Significación } \\
\text { estadística y magnitud } \\
\text { de las diferencias }\end{array}$} \\
\hline & & & $t$ & $p$ & $d$ \\
\hline \multicolumn{6}{|l|}{ Metas académicas } \\
\hline Metas de aprendizaje & $30.51(5.65)$ & $30.20(5.73)$ & 0.80 & n.s. & - \\
\hline Metas de logro & $25.58(3.74)$ & 25.38 (3.87) & 0.78 & n.s. & - \\
\hline Metas de refuerzo social & $20.54(5.48)$ & $21.14(5.17)$ & -1.63 & n.s. & - \\
\hline \multicolumn{6}{|l|}{ Estrategias de aprendizaje } \\
\hline Actitud & $29.15(5.55)$ & $27.41(5.95)$ & 4.55 & .00 & 0.31 \\
\hline Motivación & $29.62(5.61)$ & $28.87(5.81)$ & 1.95 & n.s. & - \\
\hline Gestión del tiempo & $21.77(4.11)$ & $21.17(4.10)$ & 2.16 & .03 & 0.15 \\
\hline Ansiedad & $21.51(5.24)$ & $18.60(5.61)$ & 8.06 & .00 & 0.55 \\
\hline Concentración & 27.07 (5.89) & $24.78(6.48)$ & 5.62 & .00 & 0.38 \\
\hline Procesamiento de la informac & $25.92(5.13)$ & $26.20(5.51)$ & -0.81 & n.s. & - \\
\hline Selección de ideas principales & $17.90(3.44)$ & $16.94(3.45)$ & 4.08 & .00 & 0.28 \\
\hline Ayuda al estudio & 23.37 (5.09) & $23.88(5.43)$ & -1.45 & n.s. & - \\
\hline Autoevaluación & 25.65 (4.98) & $25.80(5.27)$ & -0.44 & n.s. & - \\
\hline Estrategias de evaluación & $28.51(5.39)$ & $26.07(5.92)$ & 6.57 & .00 & 0.45 \\
\hline
\end{tabular}

Nota. n.s. = no significativo. 
Tabla 2

Resultados derivados de la regresión logística binaria para la probabilidad de presentar altas puntuaciones en metas académicas y en estrategias de aprendizaje

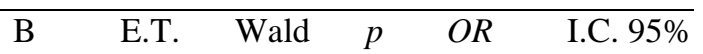

Metas académicas

\begin{tabular}{|c|c|c|c|c|c|c|c|}
\hline Metas de refuerzo social & Alta Ansiedad social & 0.42 & 0.20 & 4.17 & .04 & 1.52 & $1.02-2.26$ \\
\hline \multicolumn{8}{|l|}{ Estrategias de aprendizaje } \\
\hline \multirow[t]{2}{*}{ Actitud } & Alta Ansiedad social & -0.66 & 0.18 & 13.31 & .00 & 0.52 & $0.36-0.74$ \\
\hline & Constante & 0.13 & 0.06 & 3.88 & .05 & 1.13 & \\
\hline \multirow[t]{2}{*}{ Motivación } & Alta Ansiedad social & -0.39 & 0.19 & 4.34 & .04 & 0.68 & $0.47-0.98$ \\
\hline & Constante & 0.15 & 0.07 & 5.01 & .03 & 1.16 & \\
\hline \multirow[t]{2}{*}{ Gestión del tiempo } & Alta Ansiedad social & -0.40 & 0.19 & 4.24 & .04 & 0.67 & $0.46-0.98$ \\
\hline & Constante & 0.43 & 0.07 & 41.73 & .00 & 1.54 & \\
\hline \multirow[t]{2}{*}{ Ansiedad } & Alta Ansiedad social & -1.24 & 0.19 & 40.92 & .00 & 0.29 & $0.20-0.42$ \\
\hline & Constante & 0.20 & 0.07 & 8.67 & .00 & 1.23 & \\
\hline \multirow[t]{2}{*}{ Concentración } & Alta Ansiedad social & -.95 & 0.20 & 23.31 & .00 & 0.39 & $0.26-0.57$ \\
\hline & Constante & 0.26 & 0.07 & 14.43 & .00 & 1.29 & \\
\hline \multirow[t]{2}{*}{ Selección ideas principales } & Alta Ansiedad social & -0.70 & 0.19 & 13.82 & .00 & 0.50 & $0.35-0.72$ \\
\hline & Constante & 0.29 & 0.06 & 20.31 & .00 & 1.34 & \\
\hline \multirow[t]{2}{*}{ Estrategias de evaluación } & Alta Ansiedad social & -0.95 & 0.19 & 24.99 & .00 & 0.39 & $0.27-0.56$ \\
\hline & Constante & 0.47 & 0.07 & 45.92 & .00 & 1.60 & \\
\hline
\end{tabular}

Nota. B = coeficiente; E.T. = error estándar; $p$ = probabilidad; $O R$ = odds ratio; I.C. = intervalo de confianza al 95\%. 


\section{Acknowledgments / Agradecimientos}

This work has been funded by the SEJ 2004-07311/EDUC Project, under the Plan Nacional de Investigación Científica, Desarrollo de Innovación Tecnológica del MEC (MEC National Plan for Scientific Research and Technological Innovation Development). / Este artículo de investigación ha sido financiado a través del Proyecto SEJ 2004-07311/EDUC perteneciente al Plan Nacional de Investigación Científica, Desarrollo e Innovación Tecnológica del MEC.

\section{References / Referencias}

Alderman, M. K. (2008). Motivation for achievement: Possibilities for teaching and learning (3rd Ed.). New York, NY: Taylor \& Francis.

American Psychiatric Association (2013). Diagnostic and Statistical Manual of Mental Disorders, $5^{\text {th }}$ ed. (DSM-5). Arlington, VA: American Psychiatric Publishing.

Banerjee, R. y Watling, D. (2010). Self-presentational features in childhood social anxiety. Journal of Anxiety Disorders, 24, 34-41.

Bernstein, G. A., Bernat, D. H., Davis, A. M. \& Layne, A. E. (2008). School-based interventions for anxious children: 3-, 6-, and 12-month follow-ups. Journal of the American Academy of Child and Adolescent Psychiatry, 47, 1039-1047. doi: 10.1097/CHI.ob013e31817eecco

Cantwell, R. H. \& Andrews, B. (2002). Cognitive and psychological factors underlying secondary school students’ feelings towards group work. Educational Psychology, 22, 75-91.

Cohen, J. (1988). Statistical power analysis for the behavioral sciences (2nd Ed.). Hillsdale, NJ: Erlbaum. 
Cury, F., Elliot, A., Sarrazin, P., Da Fonseca, D. \& Rufo, M. (2002). The trichotomous achievement goal model and intrinsic motivation: a sequential mediational análisis. Journal of Experimental Social Psychology, 38, 473-481.

Delgado, B., Inglés, C. J. \& García-Fernández, J. M. (2013). Social anxiety and selfconcept in adolescence. Revista de Psicodidáctica 18(1), 179-195. doi: 10.1387/RevPsicodidact.6411

Delgado, B., Inglés, C. J. \& García-Fernández, J. M. (2014). Ansiedad social subclínica y rendimiento académico en la adolescencia: análisis de sus implicaciones teórico-prácticas. Estudios de Psicología, 35(1), 58-79.

doi: 10.1080/02109395.2014.893649

De Maris, A. (2003). Logistic regression. In J. A. Schinka \&W. F. Velicer (Eds.), Research Methods in Psychology (pp. 509-532). New Jersey: John Wiley and Sons.

Egger, H. L., Costello, E. J. \& Angold, A. (2003). School refusal and psychiatric disorders: A community study. Journal of the American Academy of Child and Adolescent Psychiatry, 42, 797-807.

García-López, L. J., De Los Reyes, A. \& Salvador, M. C. (2015). Assessment of social anxiety in adolescents. In K. Ranta, A. M. La Greca, L. J. García-López \& M. Marttunen (Eds.), Social Anxiety and Phobia in Adolescents: Development, manifestation and intervention strategies (pp. 121-150). Cham, Switzerland: Springer International Publishing.

González-Pienda, J. A., Núñez, J. C. \& García-Rodríguez, M. S. (2006). Estrategias de aprendizaje. In J. A. González Pienda \& J. C. Núñez (eds.) Dificultades del aprendizaje escolar (pp. 127-155). Madrid: Pirámide. 
Hayamizu, T. \& Weiner, B. (1991). A test of Dweck's model of achievement goals as related to perceptions of ability. Journal of Experiemental Education, 59(3), 226-234.

Inglés, C. J., Delgado, B. García-Fernández, J. M. Ruiz-Esteban, C. \& Díaz-Herrero. A. (2010). Tipos sociométricos y estilos de interacción social en una muestra de adolescentes españoles. Spanish Journal of Psychology, 13, 728-738. doi: $10.1017 / S 1138741600002390$

Inglés, C. J., García-Fernández, J. M., Castejón, J. L., Valle, A., Delgado, B. \& Marzo, J. C. (2009). Reliability and validity evidence of scores on the Achievement Goal Tendencies Questionnaire in a sample of Spanish students of compulsory secondary education. Psychology in the Schools, 46, 1048-1060.

Inglés, C. J., Marzo, J. C., Castejón, J. L., Núñez, J. C., Valle, A., García-Fernández, J. M. \& Delgado, B. (2011). Factorial invariance and latent mean differences of scores on the achievement goal tendencies questionnaire across gender and age in a sample of Spanish students. Learning and Individual Differences, 21, 138143. doi:10.1016/j.lindif.2010.10.008

Inglés, C. J., Martínez-Monteagudo, M. C., García-Fernández, J. M., Valle, A. \& Castejón, J. L. (2015). Perfiles de orientaciones de metas y autoconcepto de estudiantes de Educación Secundaria. Revista de Psicodidáctica, 20(1), 99-116. doi: 10.1387/RevPsicodidact.1023

Knappe, S., Sagagawa, S. \& Creswell, C. (2015). Developmental epidemiology of social anxiety and social phobia in adolescents. In K. Ranta, A. M. La Greca, L. J. García-López \& M. Marttunen (Eds.), Social Anxiety and Phobia in Adolescents: Development, manifestation and intervention strategies (pp. 3970). Cham, Switzerland: Springer International Publishing. 
Linnenbrink, E. A. \& Pintrich, P. R. (2000). Multiple pathways to learning and achievement: the role of goal orientation in fostering adaptative motivation, affect and cognition. In C. Sansone \& J. M. Harackiewicz (Eds.), Intrinsic and extrinsic motivations. The search for optimal motivation and performance (pp. 195-227). Londres: Academic Press.

McKenzie, K., Gow, K. \& Schweitzer, R. (2004). Exploring first-year academic achievement through structural equation modelling. Higher Education Research \& Development, 23, 95-112.

Núñez, J. C., González-Pienda, J. A., García, M. S., González-Pumariega, S. \& García, S. I. (1998). Estrategias de aprendizaje en estudiantes de 10 a 14 años y su relación con los procesos de atribución causal, el autoconcepto y las metas de estudio. Estudios de Psicología, 59, 65-85.

Olivares, J., García-López, L. J., Hidalgo, M. D., La Greca, A. M., Turner, S. \& Beidel, D. (2002). A pilot study on normative data for two social anxiety measures: The Social Phobia and Anxiety Inventory and the Social Anxiety Scale for Adolescents. International Journal of Clinical and Health Psychology, 2, 464476.

Olivares, J., García-López, L. J., Hidalgo, M. D., Turner, S. \& Beidel, D. (1999). The Social Phobia and Anxiety Inventory: Reliability and validity in an Adolescent Spanish population. Journal of Psychopathology and Behavioral Assessment, 21, 67-78. doi: 10.1023/A:1022864211676

Quiamzade, A. \& Croizet, J. C. (2007). The social determinants of intellectual performance under threat: from interpersonal comparisons to the stereotype threat. Swiss Journal of Psychology, 66, 139-144. 
Rapee, R. M. \& Heimberg, R. G. (1997). A cognitive-behavioral model of anxiety in social phobia. Behaviour Research Therapy, 35(8), 741-56.

Roeser, R. W., Van der Wolf, K. \& Strobel, K. R. (2001). On the relation between social-emotional and school functioning during early adolescence. Preliminary findings from Dutch and American samples. Journal of School Psychology, 39, 111-139.

Turner, S. M., Beidel, D. C., Dancu, C.V. \& Stanley, M. A. (1989). And empirically derived inventory to measure social fears and anxiety: The Social Phobia and Anxiety Inventory. Psychological Assessment, 1, 35-40. doi: 10.1037/10403590.1.1.35

Van Roy, B., Kristensen, H., Groholt, B. \& Clench-Aas, J. (2009). Prevalence and characteristics of significant social anxiety in children aged 8-13 years: A Norwegian cross-sectional population study. Social Psychiatry and Psychiatric Epidemiology, 44, 407-405. doi: 10.1007/s00127-008-0445-7

Weinstein, C. E., \& Palmer, D. R. (2002). LASSI user's manual: For the Learning and Study Strategies Inventory (2nd Ed.). Clearwater, FL: H\&H Publishing Co. 